\title{
PENGARUH KEPEMIMPINAN, LINGKUNGAN KERJA DAN KOMPENSASI TERHADAP KINERJA KARYAWAN PT. BAHTERA EMPAT WISESA SHIPPING BATAM
}

\author{
Mira Yona \\ Program Studi Manajemen Universitas Riau Kepulauan \\ mirayona@yahoo.co.id
}

\begin{abstract}
ABSTRAK
Penelitian ini bertujuan untuk menguji dan menganalisis pengaruh kepemimpinan, lingkungan kerja dan kompensasi terhadap kinerja karyawan PT Bahtera Empat Wisesa Shipping. Pengumpulan data dilakukan melalui penyebaran kuesioner dan dilaksanakan pada 40 karyawan PT Bahtera Empat Wisesa Shipping Batam. Analisis data pada penelitian ini menggunakan bantuan SPSS Versi 20. Teknik sampling yang dipakai adalah metode kuesioner dan teknik pengujian data yang digunakan dalam penelitian ini meliputi uji validitas dengan analisis faktor, uji reliabilitas dengan Alpha Cronbach. Uji asumsi klasik dan analisis regresi linear berganda, untuk menguji dan membuktikan hipotesis penelitian. Berdasarkan hasil analisis dapat diketahui bahwa variabel kepemimpinan, lingkungan kerja dan kompensasi berpengaruh terhadap kinerja karyawan. Hasil analisis menggunakan koefisien determinasi diketahui bahwa 66,9\% kinerja karyawan dipengaruhi oleh variabel independen yakni kepemimpinan (X1), lingkungan kerja (X2) dan kompensasi (X3). Sedangkan sisanya 33,1\% dijelaskan oleh variabel-variabel lain diluar model.
\end{abstract}

Kata kunci : kepemimpinan, lingkungan kerja, kompensasi dan kinerja karyawan 


\section{PENDAHULUAN}

\subsection{Latar Belakang Masalah}

Dalam kehidupan sehari-hari manusia tidak pernah lepas dari kehidupan berorganisasi, karena pada kodratnya manusia merupakan makhluk sosial yang cendrung untuk selalu hidup bermasyarakat. Hal ini tampak baik dalam kehidupan rumah tangga, organisasi kemasyarakatan, bahkan pada saat seseorang memasuki dunia kerja. Seseorang tersebut akan berinteraksi, dan masuk menjadi bagian dalam organisasi tempatnya bekerja.

Dalam mencapai tujuan organisasi, setiap organisasi memerlukan sumberdaya untuk mencapainya. Sumber daya itu antara lain sumber daya alam, sumber daya financial, sumber daya ilmu pengetahuan dan teknologi, serta sumber daya manusia. Diantara sumber daya tersebut, sumber daya yang terpenting ialah sumber daya manusia. Menurut Sadili (2009: 21) mengartikan sumber daya manusia adalah orang-orang yang merancang dan menghasilkan barang atau jasa, mengawasi mutu, memasarkan produk, mengalokasikan sumber daya finansial, serta merumuskan seluruh strategi dan tujuan organisasi. Adapun pengertian SDM menurut Nawawi dalam M. Yani (2012: 1) berpendapat sumber daya manusia sebagai salah satu unsur dalam organisasi dapat diartikan sebagai manusia yang bekerja dalam suatu organisasi.

Miftah Thoha (2010: 9) mendefinisikan kepemimpinan adalah kegiatan untuk memengaruhi perilaku orang lain, atau seni memengaruhi perilaku manusia baik perorangan maupun kelompok untuk mencapai tujuan. Fiedler mengatakan kepemimpinan adalah pola hubungan antar individu yang menggunakan wewenang dan berpengaruh terhadap orang lain atau sekelompok orang agar membentuk kerjasama untuk menyelesaikan suatu tugas. Sedangkan Martinis Yamin dan Maisah (2010: 74) kepemimpinan adalah suatu proses mempengaruhi yang dilakukan oleh seseorang dalam mengola anggota kelompoknya untuk mencapai tujuan organisasi.

Menurut Nitisemito (2008:183) lingkungan kerja adalah segala sesuatu yang ada di lingkungan sekitar para pekerja dan yang dapat mempengaruhi dirinya dalam menjalankan tugas-tugas yang dibebankan kepadanya. Lingkungan kerja itu sendiri meliputi tempat bekerja, fasilitas dan alat bantu pekerjaan, kebersihan, penerangan, ketenangan, termasuk juga hubungan kerja antara orang-orang yang ada ditempat kerja. (Kadarisman, 2012:300).

Menurut Tulus dalam Jurnal Bahrul Yaman (2009) kompensasi atau balas jasa didefinisikan sebagai pemberian penghargaan langsung maupun tidak langsung, financial maupun nonfinansial yang adil dan layak kepada karyawan atas sumbangan mereka dalam pencapaian tujuan organisasi.Pada dasarnya kompensasi dikelompokkan kedalam dua kelompok, yaitu kompensasi finansial dan 
kompensasi non finansial. Selanjutnya kompensasi finansial ada yang langsung dan ada yang tidak langsung. Sedangkan kompensasi non finansial dapat berupa pekerjaan dan lingkungan pekerjaan.

Kinerja berasal dari pengertian performance. Ada pula yang memberikan pengertian performance sebagai hasil kerja atau prestasi kerja. Dalam bukunya, Wibowo menyebutkan sebuah kutipan dari Amstrong dan Baron bahwa "kinerja berarti hasil pekerjaan yang mempunyai hubungan kuat dengan tujuan strategis organisasi, kepuasan konsumen, dan memberikan kontribusi pada ekonomi. Dengan demikian, kinerja adalah tentanng melakukan pekerjaan dan hasil yang dicapai dari pekerjaan tersebut. Kinerja adalah tentang apa yang dikerjakan dan bagaimana cara mengerjakannya." (Wibowo, $2011: 7$ )

Perusahaan Pelayaran Nasional PT Bahtera Empat Wisesa Shipping merupakan perusahaan yang bergerak dibidang transportasi laut internasional. Penelitian ini memfokuskan pada karyawan Perusahaan Pelayaran Nasional PT Bahtera Empat Wisesa Shipping yang berlokasi di Batam karena disini pusat kegiatan manajerial. Kinerja karyawan yang tinggi sangatlah diharapkan oleh perusahaan tersebut. Semakin banyak karyawan yang mempunyai kinerja yang tinggi, maka produktivitas perusahaan secara keseluruhan akan meningkat sehingga perusahaan akan dapat bertahan dalam persaingan global. Karyawan dituntut untuk mampu menyelesaikan tugas dan tanggung jawabnya secara efektif dan
Volume 5 No. 2 Tahun 2018

P-ISSN 2252-5262

E-ISSN 2614-499

efisien.Keberhasilan karyawan dapat diukur melalui kepuasan konsumen, berkurangnya jumlah keluhan dan tercapainya target yang optimal.

Kinerja karyawan Perusahaan Pelayaran Nasional PT Bahtera Empat Wisesa Shipping juga dapat diukur melalui penyelesaian tugasnya secara efektif dan efisien serta melakukan peran dan fungsinya dan itu semua berhubungan linear dan berhubungan positif bagi keberhasilan bagi suatu perusahaan. Saat ini persaingan bisnis transportasi laut internasional sangatlah ketat, karena telah banyak perusahaan yang melayani jasa transportasi laut internasional. Dan setiap perusahaan memiliki strategi yang cukup menantang antara satu dengan yang lain dalam menarik penumpang untuk menggunakan jasa transportasi laut. Setiap perusahaan berlomba-lomba dalam hal memiliki sumber daya manusia yang berkualitas guna menjaga kelansungan hidup perusahaan.Dapat dibayangkan apabila perusahaan dikendalikan oleh sumber daya manusia yang kurang baik kualitasnya.Dengan adanya kenyataan tersebut menunjukkan bahwa asset organisasi yang paling penting yang harus dimiliki oleh perusahaan dan sangat diperhatikan oleh manajemen adalah asset manusia dari perusahaan tersebut. Tanpa adanya factor manusia sebuah organisasi atau perusahaan tidak akan ada.

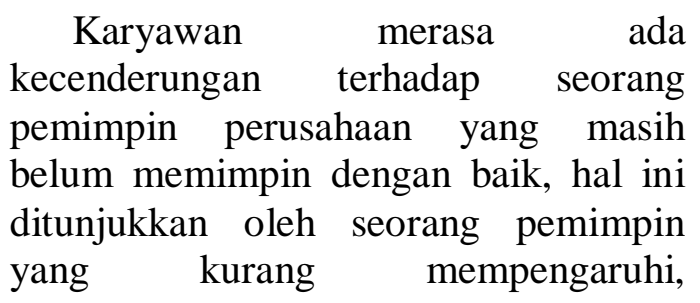


mendorong, menuntut dan menggerakkan bawahannya, sehingga karyawan kurangnya perhatian dari seorang pemimpin dari sisi lain kompensasi yang diberikan kepada karyawan terkadang diterima tidak tepat waktu, dan untuk lembur yang diterima juga tidak sebanding dengan yang dikerjakan oleh karyawan, misalnya seperti setiap akhir bulan diadakan lembur untuk mencapai target perusahaan, tetapi hitungan lembur yang diberikan oleh perusahaan tidak detail hal ini dapat mempengaruhi kinerja karyawan. perusahaan juga perlu memperhatikan lingkungan kerja untuk bisa membuat karyawan nyaman seperti hubungan kerja yang nyaman misalnya antara karyawan yang harus saling mendukung untuk mencapai targetnya perusahaan. Faktor lain yang juga berpengaruh terhadap kinerja karyawan adalah faktor lingkungan kerja. Lingkungan kerja juga berperan dalam mempengaruhi kinerja karyawan. Lingkungan yang dibina dalam perusahaan PT Bahtera Empat Wisesa Shipping diperlukan untuk mencapai tujuan perusahaan karena dengan lingkungan kerja yang nyaman, aman dan fasilitas karyawan yang terpenuhi akan mendorong karyawan untuk melakukan pekerjaan dengan optimal. Untuk mewujudkan lingkungan kerja yang kondusif perlu melibatkan pimpinan, manajemen dan karyawan itu sendiri. Lingkungan kerja di PT Bahtera Empat Wisesa Shipping yang kurang kondusif dapat dilihat dari : AC dibeberapa ruangan ada yang mati, udara yang pengap menimbulkan bau sementara karyawan harus memiliki hubungan baik ketika bekerja atau disaat berkomunikasi.

Seperti paparan latar belakang diatas, maka penulis tertarik mengkaji permasalahan tersebut dengan bentuk penulis karya akhir dengan judul

\section{"Pengaruh kepemimpinan, lingkungan kerja dan kompensasi terhadap Kinerja karyawan PT. Bahtera Empat Wisesa Shipping Batam ".}

\subsection{RUMUSAN MASALAH}

Berdasarkan uraian latar belakang yang telah dikemukakan terdahulu, maka masalah penelitian ini dapat dirumuskan sebagai berikut:

1. Apakahkepemimpinan berpengaruh terhadap kinerja karyawan Perusahaan Pelayaran Nasional PT Bahtera Empat Wisesa Shipping?

2. Apakah lingkungan kerja berpengaruh terhadap kinerja karyawan Perusahaan Pelayaran Nasional PT Bahtera Empat Wisesa Shipping?

3. Apakah kompensasi berpengaruh terhadap kinerja karyawan Perusahaan Pelayaran Nasional PT Bahtera Empat Wisesa Shipping?

4. Apakah kepemimpinan, lingkungan kerja dan kompensasi secara bersama-sama berpengaruh terhadap kinerja karyawan Perusahaan Pelayaran Nasional PT Bahtera Empat Wisesa Shipping? 


\subsection{TUJUAN PENELITIAN}

Secara umum penelitian ini bertujuan:

1. Untuk mengetahui apakah kepemimpinan berpengaruh terhadap kinerja karyawan PT Bahtera Empat Wisesa Shipping.

2. Untuk mengetahui apakah lingkungan kerja berpengaruhterhadap kinerja karyawan PT Bahtera Empat Wisesa Shipping.

3. Untuk mengetahui apakah kompensasi berpengaruh terhadap kinerja karyawan PT Bahtera Empat Wisesa Shipping.

4. Untuk mengetahui apakah kepemimpinan, lingkungan kerja dan kompensasi berpengaruh secara bersama-sama terhadap kinerja karyawan PT Bahtera Empat Wisesa Shipping.

\subsection{TINJAUAN PUSTAKA}

\subsubsection{Kepemimpinan}

Miftah Thoha (2010: 9) mendefinisikan kepemimpinan adalah kegiatan untuk memengaruhi perilaku orang lain, atau seni memengaruhi perilaku manusia baik perorangan maupun kelompok untuk mencapai tujuan.Fiedler mengatakan kepemimpinan adalah pola hubungan antar individu yang menggunakan wewenang dan berpengaruh terhadap orang lain atau sekelompok orang agar membentuk kerjasama untuk menyelesaikan suatu tugas.

\section{Indikator Kepemimpinan}

Menurut Astuti (2008), indikator kepemimpinan meliputi :

1. Kemampuan untuk memperhatikan kebutuhan karyawan

2. Usaha untuk menciptakan suasana saling percaya

3. Usaha untuk menciptakan suasana saling harga menghargai

4. Simpati terhadap perasaan bawahan

5. Memiliki sikap bersahabat, menumbuhkan peran serta bawahan dalam pembuatan keputusan dan kegiatan lain

6. Lebih mengutamakan pengarahan diri, pendisiplinan diri

7. Pengontrolan diri

\subsubsection{Lingkungan Kerja}

Menurut Nitisemito (2008:183) lingkungan kerja adalah segala sesuatu yang ada di lingkungan sekitar para pekerja dan yang dapat mempengaruhi dirinya dalam menjalankan tugas-tugas yang dibebankan kepadanya, misalnya kebersihan, musik, dan lainlain.Lingkungan kerja adalah keseluruhan sarana dan prasarana yang ada disekitar pegawai yang sedang melakukan pekerjaan yang dapat mempengaruhi pelaksanaan pekerjaan itu sendiri. Lingkungan kerja itu sendiri meliputi tempat bekerja, fasilitas dan alat bantu pekerjaan, kebersihan, penerangan, ketenangan, termasuk juga hubungan kerja antara orang-orang yang ada ditempat kerja. 


\section{Indikator Lingkungan Kerja}

Menurut Sedarmayanti, (2011), indikator lingkungan kerja fisik meliputi

1. Penerangan

2. Temperature

3. Sirkulasi udara

4. Kebisingan

5. Dekorasi

6. Bau tidak sedap

7. Keamanan

8. Pewarnaan

\subsubsection{Kompensasi}

Menurut Tulus dalam Jurnal Bahrul Yaman (2009) kompensasi atau balas jasa didefinisikan sebagai pemberian penghargaan langsung maupun tidak langsung, financial maupun non-finansial yang adil dan layak kepada karyawan atas sumbangan mereka dalam pencapaian tujuan organisasi.

\section{Indikator-Indikator Kompensasi}

Menurut Samsudin (2010) indikator-indikator kompensasi meliputi

1. Gaji

2. Insentif

3. Kompensasi finansial tidak lansung

\subsubsection{Kinerja}

Dalam buku lain di jelaskan bahwa "kinerja adalah tingkat pencapaian hasil atas pelaksanaan tugas tertentu." (Payaman J. Simanjuntak, 2011:1). Dari penjelasan ini bisa di tarik kesimpulan bahwa kinerja merupakan suatu hasil dari sebuah tindakan yang di bebankan denga tujuan tertentu, dalam hal ini tujuan yang dimaksud adalah tujuan perusahaan.

\section{Indikator Kinerja}

Mas'ud (2011) memaparkan indikator yang digunakan untuk mengukur tinggi rendahnya kinerja meliputi :

1. Kualitas kerja karyawan

2. Kuantitas kerja karyawan

3. Ketepatan waktu

4. Keterampilan

5. Tingkat pengetahuan karyawan

6. Standar profesional kerja

\subsection{KERANGKA PEMIKIRAN}

Kerangka pemikiran merupakan sintesa tentang hubungan antar variabel yang disusun dari berbagai teori yang telah dideskripsikan menurut Sugiyono (2014), Penelitian ini dilakukan untuk menguji pengaruh. Berdasarkan gambar 2.1 tersebut dapat diberi penjelasan bahwa gaya kepemimpinan (X1), lingkungan kerja (X2), dan kompensasi (X3) berpengaruh kuat terhadap kinerja karyawan(Y).

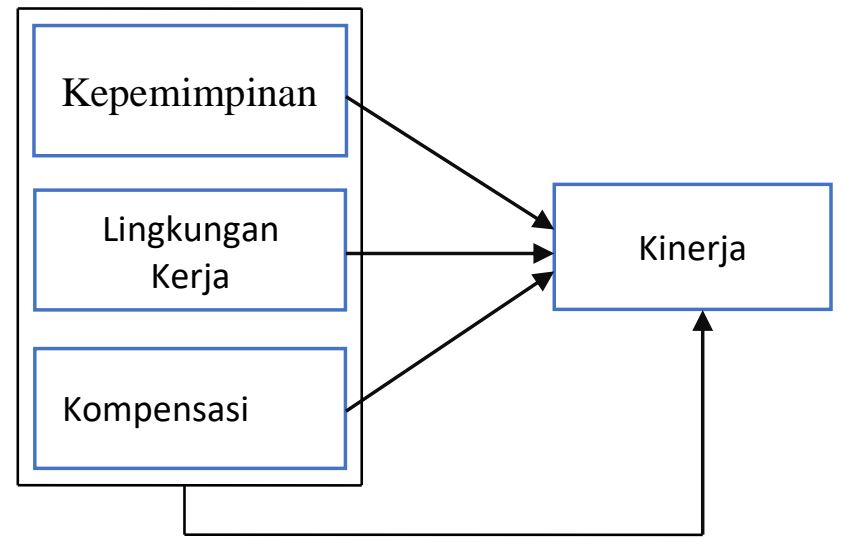




\subsection{HIPOTESA}

Berdasarkan kajian konseptual dan hasil-hasil studi empiris yang telah diuraikan, maka dirumuskan hipotesis sebagai berikut.

H1 : Diduga kepemimpinan berpengaruh signifikan terhadap kinerja karyawan

H2 : Diduga lingkungan kerja berpengaruh signifikan terhadap kinerja karyawan

H3 : Diduga kompensasi berpengaruh signifikan terhadap kinerja karyawan

H4 : Diduga kepemimpinan, lingkungan kerja dan kompensasi secara simultan berpengaruh signifikan terhadap kinerja karyawan

\subsection{METODE PENELITIAN}

\subsubsection{Objek/Subjek Penelitian}

Subjek penelitian adalah sumber yang dapat memberikan informasi permasalahan yang diteliti oleh penulis. Adapun subjek dalam penelitian ini adalah pimpinan perusahaan beserta karyawan yang bekerja di perusahaan Pelayaran Nasional PT Bahtera Empat Wisesa Shipping. Pada penelitian ini mengambil lokasi penelitian di Perusahaan Pelayaran Nasional PT Bahtera Empat Wisesa Shipping yang bertampat di Pelabuhan Internasional Batam Center.

Objek penelitian yang akan diteliti pada perusahaan PT Bahtera Empat Wisesa Shipping adalah pengaruh kepemimpinan (X1) sebagai variabel bebas, lingkungan kerja (X2) sebagai variabel bebas dan kompensasi (X3) sebagai variabel bebas terhadap kinerja karyawan (Y) sebagai variabel terikat pada Perusahaan Pelayaran Nasional PT Bahtera Empat Wisesa Shipping.

\subsubsection{Populasi dan Sampel}

Populasi adalah gabungan dari seluruh elemen yang berbentuk peristiwa, hal, atau orang yang memiliki karakteristik serupa yang menjadi pusat perhatian peneliti, karenanya dipandang sebagai semesta penelitian (Ferdianad, 2006). Populasi dalam penelitian ini adalah seluruh karyawan yang ada di perusahaan PT Bahtera Empat Wisesa Shipping yang berjumlah 40 karyawan.

Dalam penelitian ini tidak digunakan teknik sampling karena sampel yang diteliti adalah keseluruhan dari populasi yang ada atau disebut dengan sensus. Mengingat jumlah populasi hanya sebesar 40 karyawan, maka layak untuk diambil keseluruhan untuk dijadikan sampel tanpa harus mengambil sampel dalam jumlah tertentu.Sehingga sampel dari penelitian ini adalah seluruh karyawan tiap bagian unit dalam PT Bahtera Empat Wisesa Shipping.

\subsubsection{Jenis Data}

Pengumpulan data merupakan salah satu kegiatan yang dilakukan dalam proses penelitian. Dalam suatu penelitian ilmiah, metode pengumpulan data dimaksudkan untuk memperoleh bahan-bahan yang relevan, akurat dan terpercaya Supranto (dalam Haryobudi, 2010). 
jurnal
UNIVERSITAS RIAU KEPULAUAN BATAM

\section{Data Primer}

Data primer adalah data yang dikumpulkan lansung oleh objeknya, diamati dan di catat untuk pertama kalinya.Data primer diperoleh dari jawaban responden atas kuesioner yang disebarkan serta melalui wawancara dengan responden yaitu karyawan PT Bahtera Empat Wisesa Shipping.

\section{Data sekunder}

Data sekunder adalah data penelitian yang diperoleh secara tidak lansung melalui media perantara (diperoleh dan dicatat oleh pihak lain).

\section{f. Uji F (Uji F Simultan)}

Digunakan untuk menguji apakah model regresi yang digunakan sudah tepat. Ketentuan yang digunakan dalam uji $F$ adalah sebagai berikut :

1. Jika $\mathrm{F}$ hitung $>\mathrm{F}$ tabel atau nilai signifikan $<0,05$ maka model penelitian dapat digunakan atau model tersebut sudah tepat.

2. Jika $\mathrm{F}$ hitung $<\mathrm{F}$ tabel atau nilai signifikan >0,05 maka model penelitian tidak dapat digunakan atau model tersebut tidak tepat.

\subsection{HASIL DAN PEMBAHASAN}

\subsubsection{Hasil Uji Validitas}

Berikut adalah penyajian tabel hasil uji validitas per variabel dengan $\mathrm{X} 1=$ variabel kepemimpinan, $\mathrm{X} 2=$ variabel lingkungan kerja, X3= variabel kompensasi $\mathrm{Y}=$ variabel kinerja, sedangkan Qn merupakan pernyataan kuesioner. Dalam pengujian validitas peneliti menggunakan program SPSS (Statistical Program For Social Science). Item kuisioner dikatakan valid jika niai $r$ hitung $>r$ tabelnya. Nilai $r$ tabel disini adalah 0,304. Hasil pengujian validitas pertanyaan untuk variabel kepemimpinan menunjukkan seluruh pertanayaan yang digunakan valid untuk mengukur variabel kepemimpinan.

Tabel 1

Hasil uji validitas instrument variabel Kepemimpinan

\begin{tabular}{|l|l|c|c|}
\hline No. item & kolerasi & R tabel & Ketreangan \\
\hline P1 & 0,486 & 0,304 & Valid \\
\hline P2 & 0,641 & 0,304 & Valid \\
\hline P3 & 0,468 & 0,304 & Valid \\
\hline P4 & 0,558 & 0,304 & Valid \\
\hline P5 & 0,580 & 0,304 & Valid \\
\hline P6 & 0,525 & 0,304 & Valid \\
\hline P7 & 0,562 & 0,304 & Valid \\
\hline P8 & 0,576 & 0,304 & Valid \\
\hline P9 & 0,743 & 0,304 & Valid \\
\hline P10 & 0,772 & 0,304 & Valid \\
\hline P11 & 0,499 & 0,304 & Valid \\
\hline P12 & 0,705 & 0,304 & Valid \\
\hline P13 & 0,496 & 0,304 & Valid \\
\hline P14 & 0,766 & 0,304 & Valid \\
\hline P15 & 0,774 & 0,304 & Valid \\
\hline
\end{tabular}




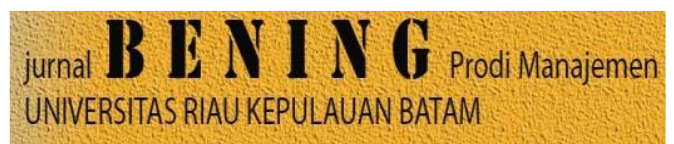

Tabel 2

Hasil uji validitas instrument variabel Lingkungan Kerja

\begin{tabular}{|l|l|l|c|}
\hline No. item & kolerasi & R tabel & ketreangan \\
\hline P1 & 0,723 & 0,304 & Valid \\
\hline P2 & 0,527 & 0,304 & Valid \\
\hline P3 & 0,515 & 0,304 & Valid \\
\hline P4 & 0,428 & 0,304 & Valid \\
\hline P5 & 0,332 & 0,304 & Valid \\
\hline P6 & 0,529 & 0,304 & Valid \\
\hline P7 & 0,381 & 0,304 & Valid \\
\hline P8 & 0,369 & 0,304 & Valid \\
\hline P9 & 0,304 & 0,304 & Valid \\
\hline P10 & 0,522 & 0,304 & Valid \\
\hline P11 & 0,483 & 0,304 & Valid \\
\hline P12 & 0,673 & 0,304 & Valid \\
\hline P13 & 0,535 & 0,304 & Valid \\
\hline P14 & 0,749 & 0,304 & Valid \\
\hline P15 & 0,729 & 0,304 & Valid \\
\hline
\end{tabular}

Tabel 3

Hasil uji validitas instrument variabel Kompensasi

\begin{tabular}{|l|l|c|c|}
\hline No. item & kolerasi & R tabel & ketreangan \\
\hline P1 & 0,903 & 0,304 & Valid \\
\hline P2 & 0,686 & 0,304 & Valid \\
\hline P3 & 0,443 & 0,304 & Valid \\
\hline P4 & 0,583 & 0,304 & Valid \\
\hline P5 & 0,666 & 0,304 & Valid \\
\hline P6 & 0,556 & 0,304 & Valid \\
\hline P7 & 0,685 & 0,304 & Valid \\
\hline P8 & 0,642 & 0,304 & Valid \\
\hline P9 & 0,823 & 0,304 & Valid \\
\hline P10 & 0,829 & 0,304 & Valid \\
\hline P11 & 0,453 & 0,304 & Valid \\
\hline P12 & 0,714 & 0,304 & Valid \\
\hline P13 & 0,782 & 0,304 & Valid \\
\hline P14 & 0,887 & 0,304 & Valid \\
\hline P15 & 0,893 & 0,304 & Valid \\
\hline
\end{tabular}

Tabel 4

Hasil uji validitas instrument variabel Kinerja

\begin{tabular}{|l|l|c|c|}
\hline No. item & kolerasi & R tabel & ketreangan \\
\hline P1 & 0,626 & 0,304 & Valid \\
\hline P2 & 0,582 & 0,304 & Valid \\
\hline P3 & 0,629 & 0,304 & Valid \\
\hline P4 & 0,521 & 0,304 & Valid \\
\hline P5 & 0,653 & 0,304 & Valid \\
\hline P6 & 0,582 & 0,304 & Valid \\
\hline P7 & 0,646 & 0,304 & Valid \\
\hline P8 & 0,497 & 0,304 & Valid \\
\hline P9 & 0,776 & 0,304 & Valid \\
\hline P10 & 0,770 & 0,304 & Valid \\
\hline P11 & 0,512 & 0,304 & Valid \\
\hline P12 & 0,504 & 0,304 & Valid \\
\hline P13 & 0,758 & 0,304 & Valid \\
\hline P14 & 0,744 & 0,304 & Valid \\
\hline P15 & 0,739 & 0,304 & Valid \\
\hline
\end{tabular}

\subsubsection{Hasil uji reabilitas}

Uji reabilitas dimaksudkan untuk menguji sejauh mana keadaan suatu alat pengukur untuk dapatdigunakan lagi dalam penelitian yang sama pengujian. pengujian reabilitas dilakukan dengan menggunakan teknik analisis Cronbach alpa.

Jika hasil $r$ hitung di konsultasikan dengan nilai tabel $r$ prodak momen dengan $\mathrm{dk}=\mathrm{N}-1$ dan signifikan 5\% maka kesimpulan diperoleh dengan membandingkan nilai $r$ hitung dengan $r$ tabel. Keputusan nya jika $r$ hitung $>r$ tabel maka instrument dikatakan reliable, dan jika $r$ hitung $<r$ tabel maka instrument tidak reliable. 
tabel 5

Hasil Uji Reliabilitas

\begin{tabular}{|l|l|l|}
\hline \multicolumn{1}{|c|}{ Variabel } & \multicolumn{1}{c|}{$\begin{array}{c}\text { Nilai } \\
\text { Cronbach } \\
\text { Alpa }\end{array}$} & Keterangan \\
\hline Kepemimpinan & 0,752 & Reliable \\
\hline $\begin{array}{l}\text { Lingkungan } \\
\text { Kerja }\end{array}$ & 0,734 & Reliable \\
\hline Kompensasi & 0,763 & Reliable \\
\hline Kinerja & 0,756 & Reliable \\
\hline
\end{tabular}

\subsubsection{Hasil uji asumsi klasik}

a. Uji normalitas

Gambar 1 hasil uji normalitas grafik histogram

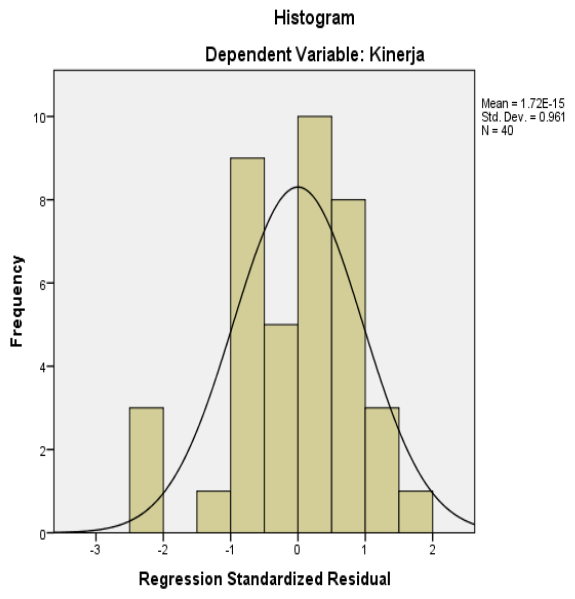

b.Uji normalitas grafik P-Plot Gambar histogram

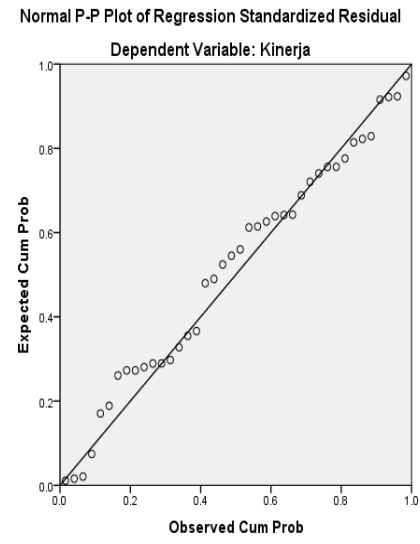

\subsubsection{Pengujian Hipotesis}

4.1.4.1 uji T ( Parsial )

\begin{tabular}{|c|c|c|c|c|c|c|}
\hline \multicolumn{7}{|c|}{ Coefficients $^{\mathrm{a}}$} \\
\hline \multirow{2}{*}{\multicolumn{2}{|c|}{ Model }} & \multicolumn{2}{|c|}{$\begin{array}{c}\text { Unstandardiz } \\
\text { ed } \\
\text { Coefficients }\end{array}$} & \multirow{2}{*}{$\begin{array}{c}\begin{array}{c}\text { Standa } \\
\text { rdized } \\
\text { coeffic } \\
\text { ients }\end{array} \\
\text { Beta } \\
\end{array}$} & \multirow[b]{2}{*}{$T$} & \multirow[b]{2}{*}{ Sig } \\
\hline & & B & $\begin{array}{l}\text { Std. } \\
\text { Error }\end{array}$ & & & \\
\hline 1 & (Constant) & $\begin{array}{l}4,96 \\
4\end{array}$ & 6,663 & & $\begin{array}{c}, 74 \\
5\end{array}$ & $\begin{array}{c}46 \\
1\end{array}$ \\
\hline & $\begin{array}{c}\text { INDEPEN } \\
\text { DEN X1 }\end{array}$ & 年, & ,318 & -229 & $\begin{array}{c}80 \\
9\end{array}$ & $\begin{array}{c}, 42 \\
4\end{array}$ \\
\hline & $\begin{array}{c}\text { INDEPEN } \\
\text { DEN X2 } \\
\end{array}$ & ,488 & ,214 & ,382 & $\begin{array}{l}2,2 \\
81 \\
\end{array}$ & $\begin{array}{c}, 02 \\
9 \\
\end{array}$ \\
\hline & $\begin{array}{c}\text { INDEPEN } \\
\text { DEN X3 } \\
\end{array}$ & ,719 & ,272 & ,712 & $\begin{array}{l}2,6 \\
46 \\
\end{array}$ & $\begin{array}{c}.01 \\
2 \\
\end{array}$ \\
\hline & Dep & & & & & \\
\hline
\end{tabular}

sumber :Data Primer Hasil Penelitian 2018 (diolah)

H1: Kepemimpinan

Pada tabel bisa dilihat bahwa nilai $t_{\text {hitung }}$ yang dimiliki sebesar $-0,809$ sedangkan $t_{\text {tabel }}$ pada $(\alpha=0.05)$ dan df 36 (40-3-1) sama dengan 1.688 ( lihat tabel distribusi $t$ ) maka $t_{\text {hitung }}<t_{\text {tabel }}$, dengan signifikan adalah $0,424<0.05$. dengan demikian berarti $h_{a}$ ditolak, secara persial kepemimpinan tidak berpengaruh terhadap peningkatan kinerja karyawan.

H2: Lingkungan kerja

Pada tabel dapat dilihat bahwa $t_{\text {hitung }}$ yang dimiliki sebesar 2,281 sedangkan $t_{\text {tabel }}$ pada signifikan $(\alpha=0.05$ ) dan df $36(40-3-1)$ sama dengan 1.688 ( lihat tabel distribusi t ) maka thitung $>t_{\text {table, }}$ dengan signifikan $0,029<0.05$. dengan demikian $\mathrm{H}_{\mathrm{a}}$ diterima, secara persial pengembangan karir berpengaruh secara signifikan terhadap peningkatan kinerja karyawan 


\section{H3: Kompensasi}

Pada tabel dapat dilihat bahwa $t_{\text {hitung }}$ yang dimiliki sebesar 2,646 sedangkan $t_{\text {tabel }}$ pada signifikan $(\alpha=0.05$ ) dan df $36(40-3-1)$ sama dengan 1.688 ( lihat tabel distribusi t) maka $t_{\text {hitung }}$ $>t_{\text {table, }}$ dengan signifikan $0.012<0.05$. dengan demikian $\mathrm{H}_{\mathrm{a}}$ diterima, secara persial komunikasi berpengaruh secara signifikan terhadap peningkatan kinerja karyawan.

\subsubsection{Hasil uji F (simultan)}

\begin{tabular}{|c|c|c|c|c|c|c|}
\hline \multicolumn{7}{|c|}{ ANOVA $^{a}$} \\
\hline \multicolumn{2}{|c|}{ Model } & $\begin{array}{c}\text { Sum of } \\
\text { Squares }\end{array}$ & Df & $\begin{array}{c}\text { Mean } \\
\text { Square }\end{array}$ & $F$ & Sig. \\
\hline \multirow[t]{3}{*}{1} & $\begin{array}{c}\text { Regres } \\
\text { sion }\end{array}$ & 1451,093 & 3 & 483,698 & $\begin{array}{c}27,25 \\
6\end{array}$ &, $000^{\mathrm{b}}$ \\
\hline & $\begin{array}{l}\text { Residu } \\
\text { al }\end{array}$ & 638,882 & 36 & 17,747 & & \\
\hline & Total & 2089,975 & 39 & & & \\
\hline \multicolumn{7}{|c|}{ a. Dependent Variable: DEPENDEN Y } \\
\hline
\end{tabular}

Hasil perhitungan statistik menunjukan nilai f hitung $=27,256>2,87$ (f tabel) dengan signifikan sebesar 0,000 $<0,05$. Yang berarti Ha diterima dan Ho ditolak, hal ini berarti bahwa secara bersama-sama Pengaruh Kepemimpinan, lingkungan kerja dan kompensasi mempunyai pengaruh yang positif dan signifikan terhadap Kinerja PT. Bahtera Empat Wisesa Shipping Batam.

\subsection{KESIMPULAN DAN SARAN}

\subsubsection{Kesimpulan}

Berdasarkan hasil penelitian dan pembahasan yang dilakukan pada bab sebelumnya, maka kesimpulan yang dapat diambil dari penelitian ini adalah :

1. Kepimpinan dalam penelitian ini secara parsial tidak berpengaruh terhadap kinerja karyawan di PT Bahtera Empat Wisesa Shipping. Hal ini ditunjukkan dengan nilai $t_{\text {hitung }}$ adalah sebesar -0.809 sedangkan $\mathrm{t}$ tabel 1.688 dan nilai probabilitas signifikansi sebesar $0.424>0.05$. Hasil tersebut menyimpulkan bahwa hipotesis $\mathrm{H}_{1}$ dalam penelitian ini ditolak.

2. Lingkungan kerja dalam penelitian ini secara parsial berpengaruh positif dan signifikan terhadap kinerja karyawan di PT Bahtera Empat Wisesa Shipping. Hal ini ditunjukkan dengan nilai thitung adalah sebesar 2.281 sedangkan $\mathrm{t}$ tabel 1.688 dan nilai probabilitas signifikansi sebesar 0.029 $<0.05$. Hasil tersebut menyimpulkan bahwa hipotesis $\mathrm{H}_{2}$ dalam penelitian ini diterima.

3. Kompensasi dalam penelitian ini secara parsial berpengaruh positif dan signifikan terhadap kinerja karyawan di PT Bahtera Empat Wisesa Shipping. Hal ini ditunjukkan dengan nilai $t_{\text {hitung }}$ adalah sebesar 2.646 sedangkan t tabel 1.688 dan nilai probabilitas signifikansi sebesar 0.012 $<0.05$. Hasil tersebut menyimpulkan bahwa hipotesis $\mathrm{H}_{3}$ dalam penelitian ini diterima.

4. Kepimpinan, lingkungan kerja, dan kompensasi secara simultan berpengaruh positif dan signifikan terhadap kinerja karyawan di PT Bahtera Empat Wisesa Shipping. Hal ini ditunjukkan dengan nilai $F_{\text {hitung }}$ sebesar 27.256 sedangkan $\mathrm{F}$ tabel 2.87 dengan nilai probabilitas signifikansi sebesar $0.000<0.05$. 
Hasil tersebut menyimpulkan bahwa hipotesis $\mathrm{H}_{4}$ dalam penelitian ini diterima.

\subsubsection{Saran}

Berdasarkan kesimpulan hasil penelitian, maka perlu dikemukakan beberapa saran berkenaan dengan peran kepimpinan dalam menjalankan roda perusahaan untuk meningkatkan kinerja karyawan di PT Bahtera Empat Wisesa Shipping sebagai berikut:

1. Peran kepimpinan sebagai kata lisator, integrator, dan berperilaku sebagai bapak perlu ditingkatkan. Sebagai leader dalam perusahaan yang merupakan motor penggerak harus menegakkan ketegasan untuk mencapai misi dan visi perusahaan.

2. Pimpinan masih perlu untuk meningkatkan usaha dalam memberikan arahan bagaimana cara melakukan pekerjaan sebagai rasa tanggungjawab dalam melaksanakan tugas.

3. Pemimpin dapat memberikan solusi terhadap pekerjaan karyawan sebagai wujud kepedulian terhadap perusahaan.

4. Selain itu penulis juga menyadari bahwa masih banyaknya kekurangan dalam penelitian ini, maka untuk penelitian selanjutnya penulis menyarankan agar menggunakan data amatan yang lebih banyak dengan menambahkan variabel-variabel lain yang lebih berpengaruh terhadap kinerja karyawan agar hasil dari penelitiannya lebih baik lagi.

\section{DAFTAR PUSTAKA}

Astuti, W. 2008. Pengaruh perilaku kepemimpinan pada kinerja pegawai dinas tata kota pekan baru. Jurnal ilmu administrasi negara. 9(2) : 73-82

Casson Robert N. 2006. Pengaruh kepemimpinan, motivasi, lingkungan kerja terhadap kinerja karyawan pada PT. Indonesia Power Semarang.

Dessler, Gery. 2006. Manajemen Sumber Daya Manusia Jilid 1. Jakarta : PT Indeks Journal, Acta Diurna, Volume III. No.4. Tahun 2014

Ghozali, Imam. 2005. Aplikasi Analisis Multivariate dengan program SPSS. Semarang: BP Universitas Diponegoro. Semarang. Journal, Acta Diurna, Volume III.No. 4 Tahun 2014

Haryobudi, 2010. Pengaruh gaya kepemimpinan, motivasi, dan kepuasan kerja terhadap kinerja karyawan pada New Metro Hotel Semarang. Skripsi Fakultas ekonomi universitas diponegoro. (Dipublikasikan)

Komaruddin, 2010 Jurnal pengaruh kepemimpinan, motivasi, lingkungan kerja, disiplin kerja terhadap kinerja karyawan pada PT. Indonesia Power Semarang.

Prof. Dr. Sugiyono. 2014. Metode

Penelitian Bisnis. Alfabeta, Bandung. Cetakkan ke-18 juli 
Samsudin 2010. Manajemen Sumber

Daya Manusia untuk perusahaan dari teori ke praktik.Jakarta : PT. Raja Grafindo Persada. Jurnal I Ketut Kusuma Yogi Antara, Pengaruh Kepemimpinan, Lingkungan Kerja.

Simamora. Henry. 2006. Manajemen

Sumber Daya Manusia, Edisi 2, STIE YKPN. Yokyakarta (Journal "Acta Diurna" Volume III No.4 Tahun 2014).

Sedarmayanti. 2011. Manajemen

Sumber Daya Manusia:

Reformasi Birokrasi dan

Manajemen Pegawai Negeri Sipil. Bandung : PT. Refika Aditama. Jurnal I Ketut Kusuma Yogi Antara, Pengaruh Kepemimpinan, Lingkungan Kerja.

Sedarmayanti. 2009. Sumber Daya Manusia dan Produktifitas Kerja, Bandung: $\quad C V . \quad M a n d a r m a j u$. Jurnal Manajemen Bisnis Petra Vol.1, No.2, 2013

Sigit, Soehardi, 2003, Esensi Prilaku

Organisasiona", Bagian Penerbit Fakultas Ekonomi, Universitas Sarjanawiyata Tamansiswa, Yokyakarta. Jurnal Pengaruh Kepemimpinan, Lingkungan Kerja Fisik dan Kompensasi terhadap Kinerja Karyawan di PT. (Persero) Daerah operasi hulu jawa bagian barat, Cirebon. 